\section{Evenwicht in Bestuurlijke vernieuwing. J.S. Mill over het belang van bestuurlijke competentie}

\section{Berry Tholen}

Dr. Berry Tholen is als bestuurskundige verbonden aan de Radboud Universiteit Nijmegen'.

Adres: Afd. Bestuurskunde, Faculteit der Managementwetenschappen, Radboud Universiteit Nijmegen, Postbus 9108, 6500 HK Nijmegen, email: b.tholen@fm.ru.nl

\section{Samenvatting}

In Nederland maar ook elders klinkt tegenwoordig een brede roep om bestuurlijke vernieuwing. De pleidooien voor verandering bevatten echter uiteenlopende gezichtspunten die elkaar soms lijken te weerstreven. Er wordt gepleit voor een versterking van controle- en verantwoordingsmechanismen. En daarnaast vraagt men aandacht voor meer en directere participatie mogelijkheden van burgers in het bestuur. In dit artikel wordt bekeken hoe J.S. Mill deze verschillende gezichtspunten in zijn beschouwing over goed bestuur bijeenbrengt. Daarbij blijkt een belangrijk derde beginsel naar voren te komen: bestuurlijke competentie. Mill wijst ons daarmee op een lacune in de gangbare hedendaagse beoordelingen van voorstellen tot bestuurlijke vernieuwing.

\section{Inleiding}

Bestuurlijke vernieuwing lijkt in vele landen in Europa, zeker ook in Nederland, een urgente zaak: op nationaal, maar zeker ook op lokaal niveau. In politieke gremia, in publiek debat en wetenschappelijke kring worden allerlei vormen van vernieuwing uitvoerig bediscussieerd. Opvallend vaak gaat het in zulke debatten om specifieke veranderingen die voorgesteld worden: vóór of tegen het referendum in enige vorm, de direct gekozen burgemeester, burgerfora, nieuwe faciliteiten om gemeenteraden te ondersteunen en noem maar op. In zulke debatten vliegen de argumenten over en weer. In opiniërende artikelen in kranten worden hele reeksen voordelen (of juist nadelen) van een bepaalde vernieuwing gepresenteerd. En in discussienota's van politieke partijen vinden we lijstjes met argumenten pro en contra. Uit zulke debatten krijgt men wel eens de indruk dat het bij voorstellen voor bestuurlijke vernieuwing eigenlijk gaat om instrumenten (of oplossingen) op zoek naar een doel (of probleem). We zullen die suggestie hier verder laten rusten. Soms overstijgt het debat de voors en tegens van concrete instrumenten. Het gaat dan nogal eens over de politieke rationaliteit achter bepaalde voorstellen tot bestuurlijke vernieuwing. Is het een manier om een bepaalde coalitiepartij tevreden te stemmen? Of is het wellicht een vlucht in institutionele veranderingen om de aandacht af te leiden van urgente inhoudelijke problemen? Ook op zulke beschouwingen zullen we hier niet ingaan. In dit artikel gaat het om bestuurlijke ver- 
nieuwingen als mogelijke oplossing voor een brede maatschappelijke problematiek, als herstel van een tekort in het hedendaags bestuur, ter remediëring van een deficiëntie in legitimiteit.

Eén belangrijke diagnose, die bestuurlijke vernieuwing inroept als oplossing, wijst op een dreigende of al bestaande kloof tussen bestuur en burgers. Daarom zijn, zo wordt betoogd, meer participatiemogelijkheden voor burgers op hun plaats (Dryzek 2000; Hirst I994; Young 2000). Daarnaast is er nog een tweede belangrijke diagnose-met-remedie aan te wijzen in de debatten. Hier worden veranderingen voorgesteld omdat bestuurders niet meer adequaat gecontroleerd worden (Bovens I995; Van Kersbergen 200I). Beide argumentatielijnen hebben duidelijk overeenkomsten. Ze verwijzen allebei naar fundamentele maatschappelijke veranderingen die de legitimiteit van het bestuur ondergraven. En bepaalde vernieuwingsvoorstellen worden wel vanuit beide diagnosen verdedigd (zoals die van de direct gekozen burgemeester in Nederland), maar op andere punten weerspreken de twee benaderingen elkaar, of leiden ze tot verschillende conclusies. Zo zien auteurs uit de tweede benadering juist door een toenemende horizontalisering en burgerparticipatie in bestuur verantwoordingsproblemen ontstaan (Klijn 2000). De pleitbezorgers voor burgerparticipatie wijzen er omgekeerd op dat door de toename van verantwoordings- en controlearrangementen burgers minder gaan begrijpen van het bestuurlijke circuit (Gray 2003: ch Io). Achter het debat over bestuurlijke vernieuwing kunnen we dus een touwtrekken ontwaren tussen pleidooien voor enerzijds 'meer participatie' en anderzijds 'meer verantwoording'. Daarmee dringt zich de vraag op of we de wenselijke verhouding tussen deze twee niet nader kunnen bepalen. Kunnen we, eventueel via een derde principe, meer zeggen over een prioritering van, of een evenwichtige verhouding tussen beide overwegingen?

Op zoek naar zo'n beoordelingskader wenden we ons in dit artikel tot het werk van John Stuart Mill. Zo'n uitstapje ligt om verschillende redenen voor de hand. Allereerst kunnen we erop wijzen dat pleitbezorgers uit beide benaderingen zich op deze Ige eeuwse auteur beroepen. Hij wordt als getuige ingeroepen om zijn aandacht voor burgerparticipatie in lokaal bestuur: omwille van burgerschapsvorming en medebestuur (Klijn 2000; Thompson
I976; Verweij 2003). Hij geldt echter ook als een exponent van de school van auteurs die zich bekommeren om adequate controle op bestuurders in een representatieve democratie (Hirst 1994). In wijsgerige overzichten wordt Mill wel neergezet als een overgangsfiguur. De laatste serieuze utilist en één van de eerste moderne liberale filosofen. Zijn werk scharnierend tussen twee liberaal-democratische tradities: een oudere traditie gefocust op de inperking van en de controle op overheidsmacht en een jongere die oog heeft voor de betekenis van politieke participatie voor burgers. In oudere studies en overzichten wordt hij veelal neergezet als een ambigu denker; falend als grondlegger van een filosofisch systeem (Sabine I973: 639). In studies van recenter datum verschijnt hij echter vaker als een verbinder, als een denker niet op zoek naar dat ene archimedische punt, maar gericht op het samenbrengen van veelsoortige overwegingen (Gray I991; Morales I996; Thompson I976).

Nog een andere reden om hier juist bij Mill te rade te gaan is dat hij een oneigentijds auteur is. Hij is niet 'gevangen' in het huidige debat met zijn typische scheidslijnen en fixaties. Daarmee kan hij ons (opnieuw) attenderen op overwegingen die buiten ons blikveld zijn geraakt. In Nederland is het niet ongebruikelijk om te rade te gaan bij een tijdgenoot van Mill in debatten over bestuurlijke vernieuwing, namelijk J.R. Thorbecke. Het aanhalen van werk of uitspraken van Thorbecke - of soms alleen zijn naam - heeft echter vaak het karakter van het aanroepen van de autoriteit van deze Nederlandse founding father. Het gaat ons hier niet om autoriteit, maar om de argumentatie van Mill. We zullen zien dat Mill inderdaad een lans breekt voor participatie en verantwoording. Om tot een evenwichtig beoordelingskader voor goed bestuur te komen brengt hij echter nog een derde aspect in het spel: competentie.

\section{Mill over goed bestuur}

De boeken van Mill die zich (nog steeds) in de grootste aandacht kunnen verheugen zijn On Liberty (I859), Utilitarianism $\left(\mathrm{I}_{86} \mathrm{I}^{2}\right)$ en The Subjection of Women (1869). Dat laatste boek krijgt veel aandacht omdat het een van de eerste uitvoerige pleidooien voor de gelijkberechtiging van vrouwen bevat. Utilitarianism en On Liberty krijgen met name in de politieke theorie en de wijsgerige ethiek aandacht vanwege de poging die Mill er doet om 
moderne rechten (waaronder dat van vrijheid van meningsuiting) een utilistische basis te geven. Vergeleken met deze werken heeft Mill's Considerations on Representative Government (I86 $\mathrm{I}^{\mathrm{I}}$, verder aangehaald als RG) een minder prominente plaats in de klassieke galerij. Alleen Mill's opmerking in dit boek dat het lokale bestuur de democratische leerschool is voor burgers wordt nog regelmatig aangehaald. Hier zullen we ons vooral richten op dit werk. Het behandelt, algemeen gezegd, de vormgeving van goed bestuur. Mill spreekt overigens van 'good government' in een brede betekenis, die zowel interne bestuurlijke organisatie als staatsbestel omvat.

Om de wijze waarop Mill de verhouding tussen verantwoording en participatie begrijpt uiteen te zetten zullen we hier eerst een schets geven van het algemene argument dat hij ontwikkelt. We starten daarvoor maar meteen bij het hoofdstuk dat de kern vormt van zijn betoog.

\section{Geen monarch!}

Het derde hoofdstuk van RG draagt als titel: 'That the ideally best form of government is representative government'. Om de stelling die in die titel vervat ligt te onderbouwen zet Mill uiteen waarom het géén goed idee is om alle staatsmacht in handen te leggen van 'an eminent individual'. Hij rekent uitvoerig af met de gedachte dat de bestuurstaak het beste vervuld kan worden met een monarch aan het roer van het schip van staat. Mill wijst er allereerst op dat zo'n monarch alwetend en alziend zou moeten zijn - hij zou op de hoogte moeten zijn van alles wat zich op elk terrein in elke uithoek van zijn territoir afspeelt en hoe daarop gereageerd zou kunnen worden. Het bestaan van zo'n bovenmenselijke getalenteerd persoon is natuurlijk weinig waarschijnlijk. Het grote gevaar zou dan ook zijn, zelfs als de monarch 'van zeer goede wil' is en niet uit is op eigen voordeel, dat hij de belangen van sommigen uit het oog verliest. De belangen van individuen en groepen zijn ermee gediend als hun eigen handen niet gebonden zijn. Het is pas zeker dat de rechten en belangen van alle individuen in ogenschouw worden genomen als ieder zelf de gelegenheid heeft en de attitude ontwikkeld heeft om voor zichzelf op te komen (Mill I86I: hoofdstuk III, 245). Een stem hebben in het eigen lot is daarbij niet alleen van belang voor het veilig stellen van directe materiële belangen van burgers, maar ook voor hun eigen ontwikkeling. Hebben ze geen stem in het bestuur, dan worden ze niet uitgedaagd om zelf na te denken en zich te verdiepen in maatschappelijke onderwerpen. Hun intellectuele ontwikkeling zou er onder leiden, maar ook de vorming van hun morele capaciteiten zou belemmerd worden (bijvoorbeeld in toewijding aan de gemeenschap, aan het algemeen belang). Bestuur met het volk ('popular government') is superieur aan een monarchie, volgens Mill, om zijn effecten van karaktervorming. Activisme namelijk, strijd leveren tegen het kwaad, vormt meer dan passiviteit. Het vormt meer in intellectuele zin (het testen en uitproberen van opvattingen), in praktisch zin (ontwikkelen van ondernemerszin) en in morele zin (leren strijd te leveren met tendenties en natuurlijke neigingen). Bovendien bestaat, volgens Mill, in een vrije samenleving minder sociaal onrecht en misdaad, en meer voorspoed. (Mill I86I' ${ }^{\mathrm{I}}$ : hoofdstuk III)

De betrokkenheid van personen uit de lower middle class in zijn eigen tijd in jury's en parish offces wijst Mill aan als belangrijke voorbeelden van vormende participatie. Hij plaatst de educatieve betekenis ervan op één lijn met deelname aan democratische instituties in het oude Athene. De rol van publieke functies op lokaal niveau benoemt hij daarmee in het bijzonder. Op dat niveau is de kans om zelf gekozen te worden groter en is er meer kans om een uitvoerend ambt te vervullen. Men kan er het makkelijkst de ontwikkeling maken van een op eigenbelang gerichte oriëntatie naar een perspectief waarin ook andere gezichtspunten en belangen meegenomen worden. Het lokale geldt voor hem dan ook als de leerschool van 'political capacity' (vgl ook Mill I86I': hoofdstuk XV).

Een bestuursvorm waarin burgers participeren is daarmee gunstiger voor individuen (zowel in directe materiele belangen als in ontplooiing) maar ook voor de samenleving als geheel (zowel in de ontwikkeling van ieders oriëntatie op algemeen belang als in algehele welstand). Zo'n bestuursvorm is volgens Mill uiteindelijk ook onafwendbaar. Als een monarch ruimte biedt voor publiek debat dan zal de publieke opinie voor of tegen hem zijn. Is ze tegen, dan zal dat uiteindelijk de ondermijning van zijn bewind betekenen; is ze voor dan is er in wezen een constitutionele monarchie. 


\section{Geen directe democratie?}

Mill concludeert dat de beste bestuursvorm die is waarbij de soevereiniteit (oftewel de hoogste controlerende macht) gesteld is in the entire aggregate of the community: every citizen not only having a voice in the exercise of that ultimate sovereignty, but being, at least occasionally, called on to take an actual part in the government, by the personal discharge of some public function. Local or general.' (Mill I86I': hoofdstuk III, 244). Op basis van de argumenten die hij geeft, oogt deze conclusie van Mill echter halfslachtig. Hij stelt hier dat soevereiniteit bij 'bevolking als geheel' en af en toe deelname in bestuur de consequentie is van zijn argumentatie - kortom een representatief stelsel. De argumenten voor bestuurlijke participatie die hij geeft leiden op zichzelf eerder tot een directe democratie. Wat is dan Mill's reden om niet deze conclusie te trekken?

Helemaal op het einde van hoofdstuk III vinden we een beknopt antwoord op die vraag: 'The participation should everywhere be as great as the general degree of improvement of the community will allow (...). But since all cannot, in a community exceeding a single small town, participate personally in any but some very minor positions of public business, it follows that the ideal type of a perfect government must be representative' (Mill I86I' hoofdstuk III, 256) Twee heel beknopt geformuleerde argumenten tegen een volledig direct democratisch stelsel vinden we hier. Een praktisch of pragmatisch argument van omvang, en een argument dat verwijst naar het niveau van ontwikkeling van de samenleving. Voor een verdere uitwerking van deze argumenten moeten we ons verder verdiepen in Mill's zoektocht naar 'goed bestuur'.

De vraag naar 'good government' kan men slechts beantwoorden, volgens Mill, als men rekening houdt met de concrete samenleving waarvoor dat bestuur moet gelden. Hij wijst echter ook de idee af dat goed bestuur een strikt particularistische aangelegenheid is: dat elke cultuur zijn eigen normen van goed bestuur heeft. Enerzijds moeten we oppassen voor een voluntarisme dat doet voorkomen als zouden we een goede bestuursvorm kunnen kiezen ongeacht de aard en opvattingen van een bepaalde samenleving. Anderzijds moeten we ons ook niet louter laten leiden door de cultuur die nu binnen een bepaalde samenleving bestaat. Dat laatste is af te wijzen om het geïmpliceerde determinisme (het heeft geen oog voor verandering en ontwikkeling) en het relativisme (er is volgens Mill wel degelijk iets te zeggen over betere en slechtere bestuursvormen in zijn algemeenheid, zie de uiteenzetting over monarchie en democratie). Als we het hebben over goed bestuur dan moeten we ons steeds afvragen welk bestuur het best past bij de capaciteit en kwaliteit van de beschikbare mensen. Specifieker: mensen 'must be willing to accept' deze vorm van bestuur. Mensen moeten verder bereid zijn het nodige te doen 'to keep it standing'. En, nog sterker, mensen moeten bereid en bekwaam zijn om te doen wat nodig is (Mill I86II: hoofdstuk I, 208/209). Een samenleving kan zich in de situatie bevinden (burgers kunnen een zodanig laag niveau van bekwaamheden hebben) dat monarchaal of zelfs koloniaal bestuur tijdelijk gepast is. Het bestuur moet dan wel gericht zijn op verdere ontwikkeling. Beoordelen we een bestuursvorm dan moeten we vragen in hoeverre de politieke instituties de wenselijke kwaliteiten van de leden van de politieke gemeenschap bevorderen, en we moeten vragen in welke mate de overheidsmachinerie is ingericht op het gebruikmaken van goede kwaliteit die bestaat 'so as to operate with the greatest effect on public affairs'. Het is vanuit deze overwegingen, zo stelt Mill, dat we in een samenleving moeten kijken naar de juiste inrichting van de bureaucratie of naar de vormgeving van de 'representative constitution' (Mill I86II : hoofdstuk II).

Daarmee krijgt het argument dat directe democratie af te wijzen kan zijn op grond van het ontwikkelingsniveau van de samenleving meer vorm. Op zichzelf biedt het echter nog steeds geen afdoende reden voor het verkiezen van een representatieve democratie boven een directe. Om dat argument te achterhalen is het nodig Mill's inrichting van dat representatieve stelsel nader te bekijken.

\section{Bestuur, participatie en verantwoording}

Een onvermijdelijk onderdeel van een representatief bestuurlijk stelsel is een controlerende assemblee, zowel op nationaal als op lokaal niveau (Mill I86II: hoofdstuk XV). Mill schetst de positie en de taken van een volksvertegenwoordiging in relatie (of contrast) tot de uitvoerende macht (het bestuur). De taak van de vertegenwoordiging is volgens hem 'to watch and control government', maar het is ook 
een 'committee of grievances' en een 'congress of opinions' (Mill I86I': hoofdstuk V, 282). De volksvertegenwoordiging vervult daarmee bij Mill in elk geval twee functies: ze biedt het bestuur de inbreng van opvattingen en ideeën van publieke opinie en ze controleert het handelen van dat bestuur. Mill bespreekt een aantal overheidstaken om zo de gepaste taakstelling van een assemblee te achterhalen. De betrokkenheid bij bestuurlijke zaken (namelijk 'administration', benoemingen en wetgeving) dient niet te groot te zijn. Het controlerende orgaan moet het bestuur de ruimte bieden. Alleen zo kan adequate controle plaatsvinden. Voor adequate controle is het verder van belang dat er één duidelijke verantwoordelijke instantie is, en dus geen versnippering van uitvoerende diensten (Mill I86I' ${ }^{\text {I }}$ hoofdstuk V, XIV). Ook een veelheid van vertegenwoordigende organen is om die reden af te wijzen. Nationaal en lokaal dienen er volksvertegenwoordigingen te zijn. Maar de vorming van meer dan één 'elected body' op lokaal niveau en van deelgemeenten is ongepast (Mill I86II : hoofdstuk $\mathrm{XV}$ ).

Mill gaat uitvoerig in op mogelijke kiesstelsels ook in zijn tijd werden allerlei stelsels met dubbele stemmen en dergelijke voorgesteld. Volledig algemeen kiesrecht acht hij van belang omdat alleen zo in beginsel ieders belang telt en burgers het vertrouwen kunnen hebben dat het staatsbestel niet slechts deelbelangen dient (Mill I86I' : hoofdstuk VIII). Gezien de verschillen in burgercompetentie kan het volgens Mill overigens, gegeven de maatschappelijke constellatie, gepast zijn dat sommigen (de hoger opgeleiden, de intelligenteren) meer dan één stem krijgen (Mill I86II: hoofdstuk VIII). Een kiesstelsel dient zodanig te zijn dat het zorgt voor een balans van 'interest groups'. Dat is om twee redenen van belang. Het mag niet gebeuren dat de belangen van een bepaalde minderheid permanent veronachtzaamd worden. Bovendien is het zeer waarschijnlijk dat ook onder minderheden verstandige lieden zijn en die behoren een kans te hebben op inbreng in de algemene opinievorming. Het kiessysteem moet met andere woorden beletten dat 'the winner takes it all' zodat verstandige geesten uit minderheden geen stem krijgen (Mill I86II: hoofdstuk VI). In een valse democratie wordt alleen de meerderheid vertegenwoordigd, in een ware democratie maken 'highly-cultivated members of community' uit alle geledingen deel uit van de assemblee. (RG hst VII) Hier wordt duidelijk hoe Mill in een vertegenwoordigend stelsel belangeninbreng en rationeel debat bijeenbrengt. In dat laatste ligt een belangrijke schakel met het argument voor vrije meningsuiting en publiek debat dat Mill in On Liberty (1859) uitwerkt. Net als in dat werk vertrouwt Mill er in RG op dat goede argumenten uiteindelijk winnen. Verandering, ook bestuurlijke verandering, is altijd mogelijk door 'de macht van

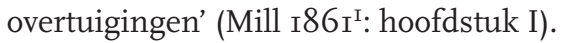

Daarmee is al aangegeven welk belang Mill hecht aan de kwaliteit van de vertegenwoordigers in een assemblee. Deze moet ingericht zijn naar 'the aquitted knowledge and practised intelligence of a specially trained and experienced few' (Mill I86I': hoofdstuk V, 284). Deze competente uitverkorenen hebben idealiter een superieure intelligentie 'trained by long meditation and practical discipline'. Vertegenwoordigers behoren uitdrukking te geven aan de opinies van degenen die hen gekozen hebben; ze zijn immers gekozen omwille van hun opvattingen. Maar vertegenwoordiging is niet een simpele kwestie van mandatering. Hun 'superioriteit' vraagt van vertegenwoordigers om optreden zonder 'last' op basis van eigen oordeelsvermogen (Mill I86II: hoofdstuk XII). Hierom ook is participatie van burgers in lokaal bestuur een goede leerschool in 'political capacity' van burgers: het brengt hen in contact met "superior minds" (Mill I86II' hoofdstuk XV, 4I7).

Mill onderscheidt volksvertegenwoordiging nadrukkelijk van bestuur. 'There is a radical distinction between controlling the business of government, and actually doing it' (Mill I86II: hoofdstuk $\mathrm{V}, 27 \mathrm{I})$. Hij geeft daarvoor twee redenen. De ene heeft te maken met specifieke bestuurlijke deskundigheid en de andere met adequate controle. Dat controle-argument kwamen we al tegen. De besturende en controlerende taak dienen daarnaast ook onderscheiden te zijn omdat elk onderdeel van bestuur een zaak van specifieke competenties of kwaliteiten is ('Every branch of public administration is a skilled business'). Elk onderdeel heeft zijn eigen specifieke principes en traditionele regels, en vele daarvan kunnen alleen bekend zijn aan degene die deze 'business' enige tijd om handen heeft gehad. Minister of lokale bestuurder zijn - of in enige geleding van een bureaucratie werkzaam zijn - vereist specifieke competenties (Mill I86II. 
hoofdstuk V, 273). Om die competentie in een bureaucratie veilig te stellen wijst Mill op precies dezelfde aspecten als Max Weber 50 jaar later zou doen (benoeming naar deskundigheid, promotie naar ervaring, duidelijke taakverdeling, enz.). Meer nog dan Weber is hij zich ook bewust van de gevaren die zo'n stelsel heeft: de routine en ervaring die enerzijds een kracht van de administratie is, kan leiden tot 'pedantocratie' van ambtenaren en bestuurders die weinig responsief worden (Mill I86I': hoofdstuk VI, 290). Omwille van een adequate controle en effectief bestuur dient het bestuur liefst eenhoofdig te zijn. Maar voor een goed en effectief bestuur is het wel noodzakelijk dat bestuurders adviseurs hebben en geregeld luisteren naar opinies, bijvoorbeeld ingebracht door adviesraden van deskundigen (Mill I86II: hoofdstuk XIV).

Het is, volgens Mill, ook een vergissing om bestuurders (ministers, president, wethouders, burgemeester) te laten aanwijzen middels verkiezingen (Mill I86I'I hoofdstuk XV). Op deze manier komen niet de meest ervaren individuen aan de leiding (Mill I86II: hoofdstuk VII, hoofdstuk XIV en hoofdstuk XV). Een reden die Mill daarvoor geeft is dat 'eminent men' veelal in hun loopbaan te veel vijanden hebben gemaakt om verkozen te worden. Bovendien worden in de (Mill's contemporaine Amerikaanse) praktijk in de regel personen gekozen op andere gronden dan politieke ervaring. En tot slot staat in een presidentieel stelsel de hele bestuursperiode in het teken van verkiezingsstrijd (Mill I86II: hoofdstuk XIV).

We begonnen deze paragraaf met Mill's these dat bestuur idealiter niet monarchaal is - bestuur in de handen van een deskundige is om verschillende redenen af te wijzen. Die redenen leken aanvankelijk tot de conclusie te moeten leiden dat directe democratie de beste bestuursvorm is. Zo'n bestuur wijst Mill echter in één zin van de hand, kortweg verwijzend naar argumenten van arbeidsdeling en het gepaste niveau van participatie in een samenleving. Nu we zijn invulling van een representatieve democratie hebben bekeken kunnen we vaststellen dat bestuurlijke competentie een sleutelrol vervult in zijn afwijzing van directe democratie. Bestuur door één (super-)deskundige is af te wijzen, maar goed bestuur vereist wel dat er specifieke competentie bestaat bij volksvertegenwoordigers, bestuurders en ambtenaren en natuur- lijk burgers. Bestuurlijke arbeidsdeling is dus niet zomaar een kwestie van pragmatiek.

Laten we de wijze waarop Mill bestuurlijke competentie begrijpt en de rol die competentie vervult in zijn idee van goed bestuur eens nauwkeuriger bekijken.

\section{Competentie en goed bestuur}

Bestuurlijke competentie als een persoonlijke kwaliteit Als Mill de idee van de ene wijze bestuurder verwerpt, richt hij zich tegen een staatsideaal zoals Plato dat in zijn Politeia uiteenzet (Plato I98I). Zo'n machtsconcentratie wijst hij af, maar zijn opvatting van bestuurlijke wijsheid of competentie is ook een andere dan die van Plato. De kwaliteiten van een goed bestuurder (maar ook die van ambtenaren of burgers) die Mill opvoert zijn niet louter cognitief (en gericht op kennis van het transcendente) maar veel aardser dan bij Plato. Zulke kwaliteiten worden namelijk ook verworven in ervaring en niet louter door intellectuele scholing en bezinning. Mill vervat de kwaliteiten van een goed bestuurder (en van dragers van andere politieke rollen) in drie trefwoorden: intellectual, moral, practical (Mill I86II: hoofdstuk II, 226/227 en in passim). Het zijn kwaliteiten die alle personen, in beginsel, kunnen verwerven. Hij wijst daarmee ook een aristocratie (de heerschappij door een 'intrinsiek' deskundiger stand of klasse) van de hand. Hij is zich er overigens wel van bewust dat door sociaal-economische verschillen personen uit bepaalde bevolkingsgroepen een grotere kans op een hogere opleiding hebben waardoor ze hun kwaliteiten beter kunnen ontwikkelen.

Met zijn opvatting van individuele kwaliteit en van de mogelijkheid en wenselijkheid die te ontwikkelen plaatst Mill zich in de Aristotelische traditie (Aristoteles I954). Ook bij Mill betekent zichzelf ontwikkelen deelnemen in maatschappelijke praktijken, waaronder met name ook de politieke. Gevormd worden betekent daarbij ook (willen) leren van meer ervarene, meer deskundige, meer hoogstaande anderen. Praktische deelname betekent in de sfeer van het politieke vooral ook deelnemen aan publiek debat: opvattingen in de strijd gooien en argumenteren. De mogelijkheid om competentie te vormen is daarbij mede afhankelijk van de structuur en ruimte die regels, 
bevoegdheidsverdelingen, e.d. bieden. Een competent bestuurder (volksvertegenwoordiger, ambtenaar, burger) kent daarbij niet alleen de regels van het spel, maar probeert ook het spel zo goed mogelijk te spelen. Bestuurlijke competentie is niet zozeer een kwestie van gedrag vertonen dat binnen de regels past, het betekent voor Mill het hebben van 'moral qualities' (van een 'deugdzame attitude' in Aristotelische termen).

Zoals al opgemerkt, wijst Mill, net als Weber later, op de noodzaak van deskundigheid van ambtenaren en bestuurders en op de noodzakelijke inrichting van de bureaucratie daartoe. Een belangrijk verschil met Weber is echter dat bij deze laatste bestuurlijke deskundigheid een kwestie is van (feiten-)kennis. Bij Mill omvat het echter ook beoordelingsvermogen en intelligentie.

Bestuurlijke competentie of kwaliteit heeft, volgens Mill, verschillende aspecten: moral, intellectual, practical. Voor een goed bestuurder zijn ze in samenhang onontbeerlijk. In lijn met Mill's argument kan men stellen dat iemand die wel specifieke kennis of deskundigheid op een bepaald terrein heeft, maar weinig van de andere aspecten van bestuurlijke kwaliteit bezit een slecht bestuurder is. Zelfs als hij 'de waarheid in pacht heeft', zo geeft Mill met zijn anti-monarchie-argumenten aan, kan het bestuurlijk verstandig zijn om bijvoorbeeld recht te doen aan de publieke opinie.

\section{Bestuurlijke competentie, verantwoording, participatie}

Het begrip competentie heeft naast de betekenis van kundigheid of kwaliteit ook die van bevoegdheid of mogelijkheid. Hoewel Mill zelf deze woordambiguïteit niet uitspeelt, heeft bij hem ook deze tweede betekenis een belangrijke rol. Om competent te kunnen worden en om competent te kunnen handelen is een zekere 'ruimte' nodig. Voor goed bestuur is het nodig dat de bestuurder discretionaire ruimte heeft en de controlerende assemblee voldoende afstand bewaart. Voor vertegenwoordigers is een adequate afstand van kiezers gepast, waardoor ze op eigen oordeelsvermogen kunnen afgaan (en, zo kan men aanvullen, burgers hebben de vrijheid (van meningsuiting) nodig om, eventueel onhoudbare, opinies in publiek debat te kunnen inbrengen). De vereisten voor competent handelen werpen daarmee een grens op voor participatie en verantwoording. Te grote participatie, te brede verantwoording belemmeren goed bestuur. Maar die noodzakelijke ruimte voor competent bestuur betekent bij Mill niet dat beginselen van participatie en verantwoording naar het tweede plan verbannen mogen worden. We memoreerden al de verschillende redenen voor burgerparticipatie. Ook voor verantwoording geeft Mill een belangrijk argument: altijd dreigt het gevaar dat bestuurders de belangen van anderen veronachtzamen. Machthebbers dienen daarom gecontroleerd te worden en verantwoording af te leggen (Mill I86I: 246).

Maar in de lijn van het gehele betoog moet bedacht worden dat sterke vereisten van verantwoording competent handelen in gevaar brengen. In termen uit de Aristotelische traditie: een sterke dwang tot verantwoording kan verantwoordelijkheid als deugd ondermijnen. Mill zag vooral gevaar in te grote bevoegdheden en een directe bemoeienis van volksvertegenwoordigers met bestuurszaken. Als paradox geformuleerd: het vergroten van verantwoordelijkheid (als aansprakelijkheid) verkleint verantwoordelijkheid (als deugdzame rolvervulling). Bij vergroting van burgerparticipatie kan een parallel effect benoemd worden. Meer participatie betekent dat het bestuur veel meer bezig is met het ontwikkelen en onderhouden van allerlei overlegarrangementen. Verplichtingen tot zulke arrangementen zeggen op zichzelf weinig, sterker nog, ze nodigen uit tot formalistisch gedrag. De bestuurlijke deugd om niet pedant te zijn, maar juist responsief, vereist geen uitvoerig overleg met burgers en groepen over alle mogelijke onderwerpen. Juist een grote hoeveelheid aan (verplicht) overleg maakt van responsiviteit makkelijk een farce.

Competentie, participatie en verantwoording verschijnen daarmee in Mill's beschouwing als drie principes die goed bestuur vormgeven. Het zijn drie principes die elkaar beteugelen, maar ook elkaar veronderstellen. Zo wordt goed bestuur (bestuur in algemeen belang) gestimuleerd door verantwoording en controle. En goed bestuur vraagt om de inbreng van participerende burgers, dat houdt de bestuurder responsief. Omgekeerd vereist adequate controle een orgaan van competente vertegenwoordigers. En de ontwikkeling van democratisch competente burgers vraagt om de omgang met capabele bestuurders en vertegenwoordigers. Zij moeten ook in staat zijn de competentsten te kiezen. Werkelijke verantwoording en 
zinvolle participatie vereisen dat bestuurders verantwoordelijk en responsief willen zijn - dat wil zeggen dat ze niet de morele incompetentie hebben van 'pedantocraten'.

\section{Mill en bestuurlijke vernieuwing}

Mill's beschouwing over goed bestuur drukt een evenwicht uit waarin de beginselen van verantwoording, participatie en competentie een centrale rol spelen. In de concrete inrichting van goed bestuur die hij schetst, blijven de arrangementen voor participatie en verantwoording beperkt. Die specifieke invulling van bestuur hoeft voor ons natuurlijk niet het laatste woord te zijn. Het is best mogelijk dat we nu, zo'n anderhalve eeuw later, op menig punt een stuk verder zijn. De samenleving die Mill voor ogen heeft (het mid-rge-eeuwse Engeland) was in vele opzichten bijvoorbeeld minder egalitair; velen genoten nauwelijks of geen scholing. Deze vaststelling zou reden kunnen zijn om voor veel verdergaande vormen van participatie te pleiten dan Mill voorstond: de democratische competentie van de bevolking als geheel is nu waarschijnlijk veel groter. Thompson bijvoorbeeld neigt tot zo'n argumentatie op basis van Mill (Thompson I976). Hij benadrukt echter nogal eenzijdig de competentie van burgers, niet die van bestuurders. Hoewel hij de betekenis van competentie in Mill's overwegingen voor het voetlicht brengt, gaat hij niet in op een (nieuwe) balans tussen competente bestuurlijke inbreng en inbreng van burgers.

Er is echter ook een andere reden om Mill's terughoudendheid jegens directe burgerparticipatie niet meteen als van andere tijden van tafel te schuiven. Goed bestuur als een midden tussen monarchie en directe democratie, zoals het door Mill wordt benoemd, is natuurlijk een poging om twee goeden te verbinden. Enerzijds het elitaire ideaal van bestuur door de meest bekwamen en anderzijds het egalitaire ideaal van individuele gelijkwaardigheid. Voor ons is het waarschijnlijk moeilijker (moeilijker dan voor de tijdgenoten van Mill) om die spanning tussen deze twee goeden vast te houden. We worden op allerlei manieren sterk doordrongen van vooral de egalitaire norm. De brede roep tegenwoordig om participatie van burgers en het navolgen van de wensen van burgers ligt in die lijn ('Als ik toch de politici kan kiezen, hoe zouden ze dan beter zijn dan ik?'). Mill wijst ons er echter op hoe en waarom een representatieve democratie (met een competent bestuur, competente volksvertegenwoordigers en competente bureaucratie) een spanningsvol, maar nastrevenswaard midden is.

Mill's perspectief nodigt ons uit om (weer) oog te hebben voor het belang van de ervaring, deskundigheid en het ethos die in elk functionerend bestuur bestaan (Warner 200I). Hij biedt een waarschuwing bij pleidooien voor meer participatie, maar ook bij de uitbreiding van verantwoordingsarrangementen. Mill's werk waarschuwt voor een beperking van de bestuurlijke ruimte door een grote bemoeienis van de controlerende volksvertegenwoordiging met het bestuur. Meer bestuur bij de controleur betekent ook minder adequaat bestuur. Verantwoordelijk bestuur maakt plaats voor op verantwoording gericht bestuurlijk handelen. De hedendaagse varianten van controle die binnendringt in bestuur zijn: monitoring, audits, midterm-reviews, en gedetailleerde output-richtlijnen of prestatiecontracten. Zulke instrumenten die beter bestuur beogen door sterkere controle en striktere verantwoording, dreigen echter juist het omgekeerde te bewerkstelligen. Ze benemen het bestuur de ruimte om op basis van eigen deskundigheid te handelen en ze maken van verantwoording een hoofdtaak. Bestuurlijk handelen dreigt ook sterk gericht te worden op gewenste output, en dat werkt easy-targetting in de hand.

De laatste tijd verschijnen er van uiteenlopende zijden kanttekeningen bij de effecten van bestuurlijke veranderingen in het recente verleden (Raad Van State 2004; Tonkens 2003; Vernieuwingsimpuls 2004). Men laat op de een of andere manier zien dat veranderingen die meer participatie en controle moesten brengen, allerlei onwenselijke gevolgen hebben. De commentaren wijzen op een belangrijke omissie in hedendaagse debatten over bestuurlijke vernieuwing. Er is aandacht voor bestuurlijke input (participatie) en voor afrekening van bestuur (verantwoording), maar niet of nauwelijks voor het functioneren van het bestuur zelf. Met behulp van het kader dat Mill ons aanreikt, is het mogelijk om de samenhang in die commentaren te benoemen: ze wijzen op veronachtzaming van bestuurlijke competenties bij vernieuwingen; vernieuwingen zijn wellicht vaak eenzijdig ingegeven door overwegingen van participatie en verantwoording. 


\section{Noten}

I Zijn onderwijs omvat de cursussen 'Binnenlands Bestuur' en 'Bestuurlijke Ethiek'. In zijn onderzoek concentreert hij zich op vragen van rechtvaardigheid en legitimiteit in bestuur en beleid. Hij publiceerde recentelijk onder meer in International Review of Administrative Sciences en in European Journal of Migration and Law.

\section{Literatuur}

Aristoteles, 1954, Ethica Nicomachea, Antwerpen: De Nederlandse Boekhandel.

Bovens, M.A.P, I995, De verplaatsing van de politiek: een agenda voor bestuurlijke vernieuwing, Amsterdam: WBS.

Dryzek, J.S., 2000, Deliberative Democracy and Beyond, Oxford: Oxford University Press.

Gray, A., B. Jenkins en F. Leeuw (red.), 2003, Collaboration in Public Services, New Brunswick: Transaction.

Gray, J. I99I, 'Introduction' in Gray, J. (red.), John Stuart Mill: On Liberty and Other Essays, Oxford: Oxford University Press.

Hirst, P.Q., 1994, Associative Democracy: New Forms of Economic and Social Governance, Cambridge: Polity Press.

Kersbergen, C. van en R. van Waarden, 200I, Shifts in governance: problems of legitimcy and accountability, Den Haag.

Klijn, E.H., J.F.M. Koppenjan, 2000, 'Interactive Decisionmaking and Representative Democracy: Institutional Collisions and Solutions' in Heffen, O.van (red.) Governance in Modern Societies. Effects, Change and Formation of Government Institutions, Dordrecht: Kluwer.

Mill, J.S., I859, On Liberty Gebruikte editie: Gray (I99I): I-I28 Mill, J.S., I86 I ${ }^{\mathrm{I}}$, Considerations on Representative Government Gebruikte editie: Gray (I99I): 203-467

Mill, J.S., I86 ${ }^{2}$, Utilitarianism Gebruikte editie: Gray (I99I): I29-2OI
Mill, J.S., I869, The Subjection of Women Gebruikte editie: Gray (I99I): 469-582

Morales, M.H., I996, Perfect Equality. John Stuart Mill on Well-Constituted Communities, Lanham.

Plato, I98I, Politeia, Amsterdam: Atheneum.

Raad van State, 2004, Jaarverslag 2003, Den Haag.

Sabine, G.H. en Th.L. Thorson, I973, A History of Political Theory, New York: Holt, Rinehart and Winston.

Thompson, D.F., I976, John Stuart Mill and Representative Government, Princeton: Princeton University Press.

Tonkens, E., 2003, Mondige burgers, getemde professionals: Utrecht: NIZW.

Vernieuwingsimpuls, 2004, 'Begeleidingscommissie Vernieuwingsimpuls Dualisme en Lokale Democratie. De positie van de wethouder: De toekomst van het verleden', Den Haag: NWO.

Verweij, M. en T.E. Josling, 2003, 'Deliberately Democratizing Multilateral Organization'. Governance I6: I-2I.

Warner, B.E., 200I, 'John Stuart Mill's Theory of Bureaucracy within Representative Government: Balancing Competence and Participation.' Public Administration Review 6I: 403-4I3. Young, I.M., 2000, Inclusion and Democracy, Oxford: Oxford University Press. 